\title{
ŠKOLA BUDUĆNOSTI - PRIKAZ DELFI STUDIJE O ALTERNATIVNIM BUDUĆNOSTIMA ŠKOLE ${ }^{1}$
}

\author{
"Da bismo kreirali budućnost obrazovanja, moramo izvesti \\ imaginativne alternativne slike budućnosti” (Toffler, 1970).
}

Na relevantna pitanja kakvo savremeno obrazovanje treba da bude, da bi odgovorilo na potrebe života u XXI veku?, kakva škola treba da bude da bi se učenici u njoj pripremali za intenzivan razvoj i neizvesnu budućnost savremenog sveta (poznatog pod sintagmom društvo rizika)?, $i$ da li obrazovanje treba da bude priprema za određene budućnosti (zvanične $i$ nezvanične) na način na koji ih vide „važni” stručnjaci, ili obrazovanje treba biti usmereno na stvaranje željenih, preferiranih vizija budućnosti?, autorke odgovore traže u futurologiji obrazovanja. Značaj futurološkog proučavanja obrazovanja se nalazi u činjenici da je svaki pristup obrazovnim reformama inherentno zasnovan na skrivenim idejama o budućnosti. Oslanjajući se na principe futurološke pedagogije, koja u proučavanju budućnosti obrazovanja uzima u obzir izmenjeni kontekst savremenog i budućeg života civilizacije, autorke predstavljaju osnovne rezultate futurološke Delfi studije realizovane sa ciljem identifikovanja potencijalnih alternativnih pravaca razvoja škola budućnosti. U radu su predstavljena tri identifikovana modela škola budućnosti - Integrisana škola, Škola kontinuiteta i Globalna škola usmerena na dete.

Ključne reči: kritička teorija obrazovanja, škole budućnosti, futurologija obrazovanja, Delfi studija.

\section{ŽELJENE NASUPROT VEROVATNIM BUDUĆNOSTIMA OBRAZOVANJA}

Kritika savremenog obrazovanja nije nov, niti sporadičan fenomen, proteže se kroz vreme obuhvatajući različite specifične dimenzije obrazovnih sistema. U istoriji pedagogije poznate su kritike aspekata obrazovnih sistema i njihov uticaj na menjanje obrazovnih politika i praksi, od obrazovanja elita ka masovnom obrazovanju, od samofinansiranog školovanja dece imućnih vlastelina ka besplatnom (javnom) obrazovanju, od obrazovanja dečaka ka obrazovanju sve dece, itd. Zna-

tamara.borovica@gmail.com Rad je nastao kao rezultat istraživanja u okviru projekta „KVALITET OBRAZOVNOG SISTEMA SRBIJE U EVROPSKOJ PERSPEKTIVI (KOSSEP)“ (br. 179010), koji finansira Ministarstvo prosvete, nauke i tehnološkog razvoja Republike Srbije. 
čajne promene su uvek bile pokretački novih formi obrazovanja. Verovatno najznačajnija kritika dovela je do uvođenja razredno-predmetno-časovnog sistema u XVII veku zajedno sa masovnim obrazovanjem i organizovanjem škole kakva je danas poznata pod imenom ,škola prema modelu fabrike”. Naredni talas kritika iz druge polovine XX veka, poznat kao radikalna kritika obrazovanja, je moguće prvi talas kritike obrazovanja koji nije doveo do traženih promena jer okosnica ovih kritika nije bila organizacija obrazovanja i učenja već društvena kontrola nad obrazovanjem i društvena reprodukcija putem obrazovanja. Aktuelna kritika obrazovanja je toliko glasna, višesmerna i sveobuhvatna da je teško sumirati. Sa jedne strane usmerena je na „,model škole kao fabrike”, prisutan u jednakoj meri četiri veka kasnije, i njegove ključne postavke (grupisanje učenika prema uzrastu, iscepkanost života i nauka na predmete, mehanicistički karakter poučavanja, ograničenost procesa učenja na 45 minuta i sl.), kao zaostatke ,industrijskog društva" koji ne odgovaraju savremenom životu. Sa druge strane, isprepletenost obrazovnih ciljeva i strategija sa društveno-političkim aspiracijama uslovljava drugačiju prirodu kritika, u čijem centru je uloga obrazovanja u reprodukciji društvenih snaga odnosno u realizaciji društveno-političko-ekonomskih agendi.

Aktuelne kritike obrazovanje su sveprisutne. Nalazimo ih u različitim naukama, disciplinama i sferama života, i preko čitavog političkog spektra (od levog ka desnom), u svim zemljama i kulturama (od Zapada ka Istoku), u teorijama obrazovanja (radikalna kritika škole, alternativne škole, pokret za školovanje od kuće), u teorijama roda i u praktično svim ,pogledima na svet“" (postmodernistički, kritička teorija, neo-Marksizam, kritički tradicionalizam i td.) (Milojević, 2005). Brojni autori smatraju da sve ove kritike ukazuju da je savremeno obrazovanje „prevaziđeno“, te da pitanje nije da li treba i da li će savremeno obrazovanje da se promeni, jer ,promena“ se ovde čini jedinom konstrantom (Holzman, 1997, Milojević, 2005, Egan, 2008, Gidley, 2008). Pitanja koja danas postavljamo su kakvo savremeno obrazovanje treba da bude, da bi odgovorilo na potrebe života u XXI veku?, kakva škola treba da bude da bi se učenici u njoj pripremali za intenzivan razvoj i neizvesnu budućnost savremenog sveta (poznatog pod sintagmom društvo rizika)?, kakva škola treba da bude da bi učenici u njoj sticali kompetence neophodne za kooperativni, stvaralački rad (koji je prepoznat kao jedan od osnovnih alata za uspeh u današnjoj ekonomiji)?, kako je organizovano učenje u ovakvoj školi? ;akva je uloga nastavnika u ovom, izmenjenom konceptu učenja?, kakav je odnos nastavnika i učenika?, kakve to nastavne metode, oblici rada $i$ aktivnosti omogućavaju učenicima da timski rade, te uče i stvaraju zajedno? Milojević dodaje još nekoliko, za nas relevantnih pitanja, da li obrazovanje treba da bude priprema za određene budućnosti (zvanične i nezvanične) na način na koji ih vide ,važni“" stručnjaci, ili obrazovanje treba biti usmereno na stvaranje željenih, preferiranih vizija budućnosti?, ako je obrazovanje priprema za određenu zadatu budućnost, kako tačno će ta budućnost da izgleda? i nasuprot tome, ako je obrazovanje stvaranje željene budućnosti, koje su to budućnosti poželjne? (Milojević, 2005:4). 
Uprkos ovim, i drugim važnim na budućnosti usmerenim pitanjima, koja neminovno pokreću na promenu, čini se da je kultura obrazovnih institucija i danas više usmerena na gledanje u prošlost umesto na osmišljavanje i planiranje budućnosti. Sofija Vrcelj uočava, citirajući R.A. Brosia, da škole imaju Janusovo lice pa gledaju u prošlost i budućnost istovremeno (Vrcelj, Mušanović, 2001). Takvo njihovo lice osim što daje dovoljno razloga za nezadovoljstvo (okrenutost ka prošlosti), daje i dovoljno podsticaja za nove početke (okrenutost ka budućnosti). Egan duhovito uočava da ,trčati brže i usavršenim stilom nimalo ne pomaže ako trčimo u pogrešnom smeru...”. (Egan, K., 2008). Na pitanje „Zašto škole toliko dugo opstaju kada ih smatramo za neefikasne?", on odgovara da su škole toliko dugo deo civilizacijske realnosti da ih smatramo za deo prirodnog sveta koji nas okružuje, čime njihovu svrsishodnost ne dovodimo u pitanje. Jednostavno, škole su tu jer treba da budu. Škola je jedna od najstarijih institucija, prva oznaka civilizacije, i oduvek je bila kakva je danas. Naravno, neke stvari su se promenile. Danas znamo više o procesima poučavanja i učenja, sazrevanju i razvoju, o menadžmentu učionice ili primeni tehnologija u učenju, kompetencijama nastavnika i standardizaciji ishoda. Ipak, suština se nije promenila. Ono što Egan primećuje kao teškoću leži u činjenici da je naš um istovremeno deo sveta i naše sredstvo posmatranja sveta. Naše ideje služe nam kao naočare koje određuju ono što vidimo. A najčešće, mi naše naočare/ideje uzimamo za gotovo i smatramo da svet doživljavamo direktno, onakvim kakav jeste (Egan, 2008). U tom smislu, popravljanjem „malih” obrazovnih problema reformama bolesnog sistema, mi u suštini ,tražimo bolji način ili stil trčanja dok i dalje trčimo u pogrešnom smeru”. Sa druge strane, isti autor uočava da čitajući knjige i tekstove o obrazovanju, stičemo utisak da, kada bi se desila ta jedna reforma nekog ključnog segmenta obrazovanja - npr. više vremena za apstraktne nauke, više slobode za učenika i njegova interesovanja, veća upotreba tehnologije u obrazovanju, fokus na razvoj veština umesto znanja, veća standardizacija ishoda učenja i sl.- škole bi funkcionisale zadovoljavajuće. Zapravo, rezultati brojnih reformi obrazovanja u praktično svim delovima sveta do danas pokazuju da, iako promena dela utiče na promenu celine, efekti ovih promena se brzo gube u opštem lošem funkcionisanju sistema (obrazovnog sistema)- naravno, sistem teži da se vrati u ravnotežu. Prema Eganu, a složićemo se sa njim, sve je jasnije da problem ne leži u pojedinačnim segmentima obrazovnog sistema već u inherentnim idejama o obrazovanju koje smo nasledili kroz istoriju zapadne civilizacije - ideja socijalizacije, Platonova akademska ideja i Rusoova ideja razvoja (Egan, 2008, 8). Sa druge strane, poznati futurolog obrazovanja Ričard Sloter smatra da su „brojne inovacije u obrazovanju za koje je znao, ili u kojima je učestvovao, odlično funkcionisale na školskom nivou. Međutim, onog momenta kada bi bile prenete na nivo obrazovnog sistema, sve se menjalo" (R.A. Slaugter predgovor u Gidley, Batemen, Smith, 2004, 2). Sloter smatra da „futurističke inicijative u obrazovanju nestaju poput dima na vetrovitom danu i ne vide se" (ibidem: 2), a osnovni razlog za to pronalazimo u činjenici da su obrazovni sistemi podređeni upravi dva seta moćnih snaga koje nemaju interesa u sferi obra- 
zovanja, zapravo, ni u sferi naše kolektivne budućnosti. Te snage on vidi u politici i ekonomiji. Još jedna značajna futurološkinja obrazovanja, Dženifer Gidli, smatra da se jedna od najvećih prepreka za izgradnju učećeg društva za budućnost nalazi se u modelu zapadne kulture, i neminovno, u njegovom inherentnom modelu obrazovanja koji promoviše globalizacija. Primarni alati globalizacije - pored ekonomskog „razvoja,,- su masovno obrazovanje i komunikacijske tehnologije, posebno Internet i masmediji (,virtuelna kolonizacija“) (Gupta, 2000, prema Gidley, 2008). Promoteri globalizacije, analizirajući i prednosti i rizike koje ona nosi, posebno tvrde da će u novonastaloj, povoljnijoj ekonomskoj klimi obrazovni, zdravstveni i drugi socio-kulturni sistemi „,cvetati“. Međutim, model razvoja koje zapadne zemlje nameću zemljama u razvoju, a sve u ime modernizacije i progresa, decenijama već brojni ne-zapadni istraživači i antropolozi razvoja vide kao drugi talas kulturnog imperijalizma (Gidley, 2008). Sa druge strane, iz Taoističke perspektive, sve u sebi sadrži seme svoje suprotnosti. Tako i projekat globalizacije, koji preti da razvije opasnije kolonizatorske i hegemonijske snage od svog prethodnika- projekta modernizma, sadrži i potencijal za snažnu emancipaciju (Gidley, 2001, prema Gidley, 2008).

Postalo je očigledno da novi alati ne donose željenu obrazovnu promenu. Moć se ne nalazi u alatu. Moć danas tražimo u promeni obrazovne paradigme (Kunovom terminologijom), a jedan od mogućih pravaca promišljanja promene obrazovne paradigme je futurologija odnosno futurologija obrazovanja. Verovatno najjednostavnija definicija obrazovanja definiše ga kao pripremu za život u budućnosti. Dimenzija budućnosti inherentno je prisutna u obrazovanju. Međutim, futurološki pristup istraživanjima obrazovanja još uvek je veoma sporadičan. Jedan od razloga za to je doživljaj futuroloških istraživanja kao „neozbiljnih“ i „,nenaučnih“, što je odbijalo svakog ,ozbiljnog“ istraživača. Ipak, značaj i efikasnost futuroloških studija u drugim oblastima (kao što su razvoj tehnologije, ekonomije, privrede i td.), dovele su do intergiranja futurologije u istraživanja obrazovanja. Fuko uočava (1973, 372, prema Milojević, 2005) da je znanje o budućnosti ili budućnostima, kao i svako drugo znanje, duboko ukorenjeno u život, društvo, jezik, te da ima istoriju. Uvođenje futurološke perspektive u obrazovanje, kroz proučavanje futurologije kao nauke ali i kroz integrisanja koncepata futurologije u postojeće nastavne discipline, deluje osnažujuće na učenike. Kada jedna budućnost (najčešće mračna i zabrinjavajuća) postane brojne budućnosti (na koje se može uticati i među kojima se može vršiti izbor), otvaraju se vrata ličnoj i kolektivnoj odgovornosti svakog pojedinca. Dakle, i učenika (Gidley, Bateman, Smith, 2004). Uočićemo dve dimenzije integracije futurologije u obrazovanje, prva je, kao što smo već pomenuli, futurološki fokus u istraživanjima obrazovanja i kreiranju obrazovnih koncepcija, dok se druga dimenzija odnosi na integrisanje koncepata budućnosti u školu kakva jeste kroz osavremenjivanje nastavnih predmeta i sadržaja i učenje o budućnosti (osnaživanje i priprema život i rad u budućnosti) (Gidley et al., 2005). Koristi od prve dimenzije smo već pomenuli a koristi od integrisanja druge dimenzije nalaze u osnaživanju učenika za akciju i smanjivanje osećaja bespomoćnosti i beznađa u odnosu na ličnu i društvenu budućnost (ibidem). 


\section{FUTUROLOŠKA ISTRAŽIVANJA U PEDAGOGIJI}

Futurologiju najopštije možemo odrediti kao nauku o budućnosti čovečanstva. Prema Pedagoškom leksikonu (1996), futurologija (lat. futuris-budući i logos-reč, govor) je nauka koja se bavi budućnošću, posebno budućnošću čovečanstva $\mathrm{s}$ obzirom na tehnički razvitak. Isti izvor kaže da je futurološka pedagogija grana pedagogije koja se bavi predviđanjem budućnosti vaspitno-obrazovnog fenomena. To je interdisciplinarno područje pedagogije i futurologije. Primenjuje postupke futurološkog istraživanja u pedagogiji. Futurološko istraživanje u pedagogiji, dalje je područje pedagoškog istraživanja koje se bavi naučnim proučavanjem budućnosti vaspitanja i obrazovanja, kako na nivou želja i potreba (normativni aspekt), tako i na nivou njegovog verovatnog razvoja, $\mathrm{tj}$. prognoze (deskriptivni aspekt). Područje je interdisciplinarno pa je takvo i futurološko istraživanje (Pedagoški leksikon, 1996). Nešto drugačija definicija futurologije, nemačkog profesora Osipa Flehtejma (Ossip Flechteim) kome se pripisuje i autorstvo termina studije budućnosti, je verovatno više u skladu sa kritičko- istraživačkom prirodom ovog rada. Prema pomenutom autoru, futurologija je nauka o kretanju civilizacije koja ima revolucionarni, složeni i alternativni karakter (Opšta enciklopedija, 1977, 82). Istraživanje budućnosti je područje multidisciplinarnog i interdisciplinarnog pristupa kojim se društveni fenomeni žele svestrano istražiti. U svim ovim istraživanjima, bez obzira na područje, promena je istaknuta kao konstanta. Na temelju istraživačkih rezultata, prognozama se upozorava na opasne posledice određenih trendova prirodnih, tehničkih i društvenih fenomena, te predlažu moguća rešenja (Vrcelj, Mušanović, 2001, 48).

Futuristička fluentnost, kako je definiše Vendi Šulc (Wendy Shultz), predstavlja izuzetnu veštinu i zadovoljstvo u kritičkoj, kreativnoj i konstruktivnoj primeni strogo imaginativnih spekulacija (Schultz, 1998, prema Gidley, Bateman, Smith, $2004,25)$. Sulcova dalje definiše pet ključnih koraka futurološke fluentnosti, to su:

1. identifikovanje i praćenje promena prvenstveno analizom nastajućih problema/ fenomena (tzv. skeniranje sredine),

2. analiziranje efekata promene, zasnovano na analizi uticaja (futurološka metoda)

3. imaginacija alternativnih budućnosti bazirana na inkastingu (deduktivno predviđanje mogućih budućnosti),

4. osmišljavanje željenih budućnosti ili ideala na osnovu vizioniranja (imaginativni, idealistički ili normativni proces koji pomaže u identifikovanju željenih budućnosti),

5. planiranje i sprovođenje/ faza realizacije koja uključuje „backcasting” koji premošćava jaz između moguće (odnosno željene) budućnosti i proširene sadašnjosti ("backcasting" podrazumeva predviđanje i identifikovanje poželjne budućnosti i pravljenje strategija za njego realizovanje) (Schultz, 1998, prema Gidley, Bateman, Smith, 2004, 25).

Konačno, nakon što su svih pet faza realizovane, sledi povratak na početak i identifikacija, praćenje i analiza efekata promene koja se desila. 
Futurološke studije su usmerene na dugoročna razmišljanja i planiranja, i kao takve nedovoljno primenjivane u obrazovanju. Na osnovu njihovih rezultata, zadatak obrazovnih politika bio bi da identifikovane poželjne scenarije razvoja obrazovanja učine verovatnim ili aktuelnim, odnosno da prave strateške puteve za približavanje verovatnih ili mogućih scenarija razvoja obrazovanja poželjnim scenarijima. Futurološke metode su usmerene na predviđanje i povezivanje današnjice sa nekom vremenskom tačkom ili stanjem u budućnosti, tako što ispituju šta znamo ili možemo znati, koje su raspoložive opcije razvoja, koje su opcije poželjne a koje nepoželjne, kako delovati da se povećaju izgledi željenih i smanji verovatnoća pojavljivanja nepoželjnih ishoda. Metodologija futurologije podrazumeva primenu naučnih metoda i postupaka sa ciljem da se apstrahuju, odnosno protumače i shvate činjenice, događaji i procesi koje očekujemo u budućnosti (Suzić, 2012, 25). Tema našeg istraživanja je identifikovanje potencijalnih alternativnih pravaca razvoja škola budućnosti, iz čega se vidi naše opredeljenje za pristup futurološke pedagogije, koji u proučavanju budućnosti obrazovanja uzima u obzir izmenjeni kontekst savremenog i budućeg života civilizacije.

Budućnost odnosno alternativne budućnosti obrazovanja su vizije potencijalnih škola budućnosti i kreću se od verovatnih, preko mogućih do željenih scenarija ili vizija budućnosti obrazovanja (autori danas dodaju i četvrti pravac a to su planirane ili očekivane budućnosti -engl. prospective futures). Alternativne budućnosti obrazovanja su raspon opcija ili puteva pred nama, one nam ukazuju da ne postoji jedna budućnost ka kojoj idemo već obilje mogućnosti a svaka krucijalna odluka koju donesemo figurativno predstavlja ,skretanje na raskrnici” mogućnosti i biranje određenog pravca. Naravno, planiranje budućnosti, posebno u važnoj oblasti kao što je školovanje, sa jedne strane nosi ogromnu odgovornost, dok sa druge strane nudi nadu i optimizam i osećaj da nismo bespomoćni, da postoje načini, mogućnosti i resursi za menjanje onoga što nas plaši. Najveći strah svih nas koji verujemo u obrazovanje je verovatno strah od raškolovanja društva i preterane tehnologizacije obrazovanja. Za oslobađanje ovog straha neophodne su nam dve promene dominantnih paradigmi u obrazovanju. Prva promena se odnosi na promišljanje budućnosti obrazovanja (u kontekstu verovatnih, mogućih i željenih budućnosti) kao protivteže „,srljanju” u budućnost (i nametnutim „hegemonijskim" budućnostima), dok se druga promena odnosi na prelaz sa identifikovanja jedne jedine budućnosti (pozitivistička, empirijska paradigma) ka traganju za alternativnim budućnostima (kulturna, interpretativna paradigma) i naposletku ka „futurisanju” (integrativna, transformatorska, osnažujuća paradigma) (Gidley et al., 2004).

\section{DELFI METOD}

Fokus većine Delfi istraživanja je pouzdano i kreativno istraživanje ideja ili dolaženje do novih informacija, korisnih pri donošenju važnih (strateških) odluka. Iako je Delfi metod nazvan prema grčkom svetilištu u Delfima, gde su proročice 
pod imenom Pitije predskazivale, često dvosmislene, budućnosti, autori metoda u početku nisu bili zadovoljni ovakvim nazivom jer je ukazivao na okultizam i mističnost. Zapravo, osim imena, Delfi metod nema ništa drugo mistično u sebi, i svakako ne predstavlja sredstvo otkrivanja budućnosti (jedne, jedine, zapisane). U pitanju je kvalitativan, normativan i eksplorativan istraživački dizajn.

U literaturi se često ističu prednosti primene Delfi metoda u menadžmentu ali i istraživanjima pitanja obrazovanja, posebno planiranja obrazovanja (Nash, 1978, prema Moravec, 2007). Gordon ukazuje i na sve češće upotrebu Delfija u medicinskim istraživanjima (Gordon, 2003, 5). Neš smatra da je metod posebno prigodan za rad sa ekspertskim grupama koje nisu često uključene u istraživanja. Npr, istraživanja liderstva u obrazovanju, gde primena Delfi metoda može dovesti do indirektnih koristi koje originalnim nacrtom istraživanja nisu predviđene. Neke od ovih koristi su razjašnjavanje ideja ili činjenica, istraživanje alternativnih perspektiva i mogućnosti, razvoj kritičkog, kreativnog i sistemskog mišljenja i td., kod učesnika istraživanja. Takođe, pored primene za postizanje grupnog konsenzusa o pitanjima budućnosti, Delfi metod može biti primenjen kao podsticaj grupi za bolje osmišljavanje budućnosti.

Delfi metod se vremenom razvijao i danas teško da možemo reći da postoji saglasnost oko toga kako precizno jedna Delfi studija treba da izgleda. Varijacije istraživačkog pristupa su dovele do formiranja mini-Delfija i „Delfnih” studija, koje se često kombinuju sa drugim istraživačkim metodama. Prema Gordonu (2003), da bismo istraživanje nazvali Delfi studijom, ono mora da sadrži sledeće korake:

1) osmišljavanje istraživačkih pitanja,

2) identifikovanje članova ekspertskog uzorka i pozivanje na učešće u istraživanju,

3) distribucija upitnika i prikupljanje podataka,

4) utvrđivanje raspona mišljenja izraženih u upitnicima,

5) kreiranje drugog upitnika i prosleđivanje svim ekspertima u uzorku, uz napomenu ekspertima na ekstremnim pozicijama da preispitaju svoje odgovore i navedu razloge zbog kojih su njihovi stavovi toliko drugačiji,

6) kreiranje trećeg upitnika i prosleđivanje svim ekspertima uz ponovnu napomenu ekspertima na ekstremnim pozicijama da preispitaju svoje odgovore $i$ navedu argumente za svoje stavove,

7) ukoliko je neophodno, kreiranje četvrtog upitnika i prosleđivanje uzorku radi finalne procene.

Međutim, varijacije su sve češće te se u nekim savremenijim formama Delfi studija umesto upitnika primenjuju dubinski interjui sa ekspertima, dok se u nekim drugim održavaju grupni sastanci eksperata. Takođe, grupni konsenzus u novijim studijama često nije neophodan, već se fokus studija usmerava ka kreiranju opcija ili alternativa (Gordon, 2003). Upravo tako je zamišljena Delfi studija primenjena u ovom istraživanju, kao podsticaj ekspertima koji se bave pitanjima obrazovanja i razvoja obrazovanja u budućnosti, za osmišljavanje alternativnih vizija škola budućnosti. 


\section{DELFI STUDIJA ALTERNATIVNIH MODELA ŠKOLA BUDUĆNOSTI}

S obzirom da budućnost ne znamo i ne možemo je tačno predvideti, ono čime se futurolozi bave su, u stvari, ideje, predstave o budućnosti, nastale na osnovu naših istorija, ideologija i trendova koji upravljaju aktuelnim razvojem (što nije garant njihovog uticaja u/na budućnost) (Milojević, 2005). Kritička analiza budućnosti je, u tom smislu, neophodna kako bismo razotkrili nametnute scenarije (zadate) budućnosti i umesto njih kreirali vizije alternativnih budućnosti. Kritička futurološka analiza je ključna jer olakšava prepoznavanje da je svaki pristup obrazovnim reformama inherentno zasnovan na skrivenim idejama o budućnosti (i vremenu) (Milojević, 2005, 18). Naše slike o budućnosti (vizije ili scenariji budućnosti) neminovno utiču na donošenje odluka u praktično svim sferama života pa i u obrazovanju, kritičkom analizom kako ovih slika (scenarija) budućnosti a potom i veze između njih i obrazovnih sistema/strategija, možemo stvoriti uslove za razvijanje alternativnih obrazovnih vizija. Međutim, značajno je reći da ove alternativne budućnosti nisu „konačne vizije”, one nikako ne ukazuju da je budućnost „otkrivena”. Alternativne vizije predstavljaju takođe deo prakse „konstrukcije” i „,rekonstrukcije" stvarnosti, kreirane iz određene perspektive. U našem slučaju iz interpretativne, kritičke i hermeneutičke perspektive proučavanja obrazovanja.

Kvalitativna studija izložena u nastavku teksta dizajnirana je u skladu sa fenomenološkom istraživačkom filozofijom i induktivnim metodološkim pristupom. Ovakav pristup omogućio je da se od pojedinačkih podataka induktivnom logikom stvaraju teorijski konstrukti. Osnovna paradigma našeg istraživanja je interpretativna (hermeneutička) paradigma, prema kojoj stvarnost nije jedna i nije objekat koji se može otkriti i meriti, već je stvarnost konstrukcija našeg mišljenja.

Poziv za učešće u istraživanju dobilo je 60 stručnjaka u oblasti budućnosti obrazovanja i/ili futurologije a pozitivan odgovor na poziv uputilo je 15 istraživača. S obzirom na specifičnost ciljne grupe, Delfi studija je realizovana u jednom ciklusu, bez postavljanja dodatnih pitanja i zadataka učesnicima. Za potrebe našeg istraživanja, rezultati Delfi studije urađene na uzorku intenziteta od 15 eksperata iz oblasti obrazovanja i futurologije obrazovanja iz različitih zemalja i kultura (iz regiona i sa pretežno engleskog govornog područja), iskorišćeni su za skiciranje alternativnih modela škola budućnosti. Cilj ovih modela, dakle, nije utvrđivanje tačne ili najbolje verzije budućnosti škole, već otvaranje što više alternativa, širenje perspektiva pri sagledavanju budućnosti obrazovanja, kritička analiza nametnutih (hegemonijskih) vizija i stvaranje imaginativnih vizija potencijalnih škola budućnosti.

Naš istraživački pristup je dizajniran tako da ostavi što više slobode i autentičnosti svakom od učesnika istraživanja. Formulacijom jednostavnih, otvorenih, refleksivnih pitanja stvorili smo prostor za svakog od eksperata da izdvoji one elemente škole budućnosti koje autentično prepoznaje kao bitne, suštinske i potrebne, kao i da samostalno situira pravce promene unutar školskog konteksta (npr. 
implicitni kurikulum, filozofija obrazovanja, organizacija života i rada škole, učenje i poučavanje, $\mathrm{i}$ td.) bez navođenja od strane istraživača u kom smeru ovo vizioniranje treba da ide. Konkretnija pitanja, pretpostavljamo, donela bi više informacija i, pretpostavljamo, jasnije strukture vizija škola budućnosti, neminovno uslovljeno narativom škole budućnosti istraživača. Kako bismo izbegli nametanje ovih ličnih narativa istraživača, ekspertima su postavljena četiri široko koncipirana pitanja na osnovu kojih su razvijali svoje vizije preferirane budućnosti škole. Pitanja su se odnosila na: koncepciju (viziju) škole budućnosti ostvarive u narednih 50 godina (1.), ciljeve ovakve škole i filozofiju obrazovanja iza nje (2.), arhitekturu i organizaciju škole budućnosti (3.), kao i razloge zašto baš takva škola treba da bude cilj kome teži aktuelno obrazovanje (4.). Dobijeni rezultati, s obzirom na specifičnost istraživačkog pristupa (međunarodni ekspertski uzorak), nisu ujednačavani ni diskutovani sa ekspertskim uzorkom u narednim fazama istraživanja (što bi bilo očekivano za Delfi pristup). Naprotiv, sve ideje dobijene Delfi studijom uzete su kao materijal za izgradnju vizija poželjnih škola budućnosti, uz neminovnu dominaciju ideja koja su se ponavljale i češće pojavljivale u odnosu na specifičnije ideje samo jednog eskperta. Originalni nacrt Delfi studije bi zahtevao diskutovanje dobijenih scenarija sa celokupnim ekspertskim uzorkom i rad na dobijanju konsenzusa o poželjnom pravcu razvoja škole budućnosti. S obzirom da u futurologiji danas govorimo o budućnostima, verovatnim, mogućim, preferiranim i/ili planiranim budućnostima, uključujući i budućnosti škole, svako ujednačavanje i potraga za jednom, poželjnom, „,najboljom” budućnošću škole bila bi pogrešna. Iz tog razloga, naša studija fokusirana je na dobijanje što većeg broja alternativnih pravaca i alternativnih ideja za dalje konstruisanje scenarija poželjnih ka planiranim budućnostima škole. Druga specifičnost naše studije došla je kao iznenađenje istraživačima, a nalazi se u činjenici da je većina eksperata u našem uzorku, o školi/školama budućnosti vizionirala u prevashodno sličnom pravcu. Dakle, dobijeni rezultati nisu nam omogućili razvijanje alternativnih scenarija budućnosti obrazovanja, što je bio jedan od ciljeva ovog istraživanja. Nasuprot tome, dobijeni podaci su omogućili razvijanje sveobuhvatnijeg narativa nekoliko poželjnih škola budućnosti.

\section{NAJVAŽNIJI REZULTATI DELFI STUDIJE}

Uslovi za manifestaciju preferiranih škola budućnosti:

Polazna osnova, oko koje su se eksperti ne znajući složili, odnosi se na neophodnu značajnu promenu društvenog konteksta kako bi se stvorili uslovi za željene promene obrazovanja o kojima govore. Bez prethodne promene društvenog konteksta (političkog, ekonomskog, kulturnog, vrednosnog i td.), ni jedna od vizija škola budućnost nije moguća i ne bi bila održiva. Današnje društvo, sa neskrivenom društvenom i političkom dominacijom nad obrazovanjem, ne predstavlja plodno tlo za razvoj željenih pravaca škola budućnosti, prema našem uzorku eksperata. Jedna od neophodnih transformacija, da bi se desila škola budućnosti, je 
prethodna socijalna transformacija u smeru razvoja društva koje je usmereno na zadovoljavanje čovekovih potreba, a ne prvenstveno na profit. Među mogućim pravcima izazivanja ovih promena, izdvaja se veći uticaj organizacija civilnog sektora na promene obrazovnih politika. I ne samo na promene obrazovnih politika, već i na promene u smeru ostvarivanja pluralizma pedagoških školskih modela, kao jedinog načina da škola budućnosti odgovori na različite specifičnosti, očekivanja i zahteve, različite dece, roditelja, nastavnika i zajednica.

Za bilo kakvo razmišljanje o školama budućnosti, neophodno je promišljanje alternativnih budućnosti civilizacije. Ono što ovde postaje jasno je da bez ovakvih značajnijih društvenih promena, savremeno obrazovanje ide u dva pravca; sa jedne strane ka sve većem okoštavanju i formalizovanju obrazovnih sistema (bez značajnijih promena u narednih 50 godina), dok sa druge strane ka eventualnom slomu aktuelne škole usled velikog nezadovoljstva roditelja i učenika i javljanju sve brojnijih i atraktivnijih obrazovnih tehnologija (od programiranog udžbenika ka simulaciji kao sredstvu učenja). Ni jedna od ove dve alternative ne predstavlja preferirane budućnosti škole. S obzirom da smo se ovim istraživanjem fokusirali samo na preferirane budućnosti škole, a izostavili analize verovatnih, izvesnih ili planiranih budućnosti, niz pitanja koja se ovde pojavljuju ostaju otvorena za neke druge prilike. Najočiglednija od njih su: Kakve su izvesne budućnosti škole?; Šta su planirane budućnosti škole u ovom momentu?, i Kako od izvesnih voditi ka preferiranim budućnostima škole?

Da bismo kreirali alternativne obrazovne pristupe, treba da svaki dan radimo drugačije i to svi, nastavnici, učenici, roditelji, zajednice, da gradimo (perform) obrazovne budućnosti. To takođe znači da moramo osigurati manju ili nikakvu prisutnost politike u obrazovanju, odnosno neutralnost donosioca odluka po pitanju obrazovnih filozofija i pristupa. Dalje, neophodno je ulaganje u obrazovanje kao društveni prioritet, poštovanje i vrednovanje rada svih aktera nastavnog procesa. Tek osiguravanjem ovakvih preduslova, prema rečima jednog od eksperata, „forma današnje škole biće nadomeštena suštinom škole budućnosti”.

Vizije preferiranih pravaca razvoja škola budućnosti:

U prvoj analizi naših Delfi upitnika, jasno su se izdvajile se dve dominantne i oprečne vizije budućnosti škole. Prema prvoj od ove dve vizije, nazvaćemo je Integrisana škola, škola ne postoji, a učenje se odvija svugde, uvek, i od strane svakog, kroz kontinuirane obrazovne interakcije uvek i svugde (prostori za učenje i vreme za učenje zamenjuju instituciju škole). Učenje je postalo nevidljivo, ispunjava svaku poru društva i predstavlja neodvojivi deo društvenog života. Škola je utemeljena u zajednici, ustanova koja ispunjava lokalne i globalne potrebe podstičući učenike da postanu aktivni učesnici u suštinskim procesima kulture. Primer ovakve škole budućnosti je Zukoti park (Zuccotti park) tokom Okupiraj Vol strit pokreta. Ovde je na delu potpuna relativizacija vremena, prostora, aktera i disciplina učenja, uz veliku zastupljenost alternativnih modela škole, uključujući i e-učenje.

Nasuprot ovoj školi, izdvojila se Škola kontinuiteta, koja predviđa da će škola kao institucija i u budućnosti neminovno i neizmenjeno opstati, upravo zbog ve- 
likih mogućnosti uticaja na mlade. Obrazovanje je plodno tlo političkih manipulacija, dakle dok je politike biće i škole. Obrazovanje ima ulogu da predstavlja granicu između sećanja i tradicije sa jedne strane i imaginacije i ekspanzije sa druge strane, zbog toga će obrazovanje uvek biti mesto socijalnog pregovaranja. Da li će Škola kontinuiteta opstati oslanjajući se na obrazovne filozofije na koje se danas oslanja, nije se pokazalo vidljivim u našoj studiji. Međutim, s obzirom da je krucijalni element kontinuiteta ovde upravo društveno-političko uticanje na decu i mlade, prvi preduslov za realizaciju preferiranih budućnosti se dakle ne ostvaruje. Induktivnim putem mogli bismo zaključiti da Škola kontinuiteta ne predviđa velike i značajne promene u samoj obrazovnoj filozofiji i politici. Takođe, zanimljivo je primetiti da niti jedan od eksperata u našem uzorku ne izdvaja Školu kontinuiteta kao preferirani model škole budućnosti a ona se ipak pojavila kao izdvojeni model u studiji o željenim vizijama škola budućnosti. Kakva je njena uloga ovde, ostaje za promišljanje.

Razmišljajući o školi koja bi mogla opstati i biti funkcionalan deo društva budućnosti, većina eksperata vizionira u sličnom pravcu. Zapravo, treći model škole koji ćemo upravo opisati je najpribližnije scenariju škole budućnosti što smo ovim istraživanjem dobili, i jedini delimično potpun model škole budućnosti koji zavisi od gore navedenih uslova za ostvarenje željenih budućnosti obrazovanja. Dakle, kao preferirani model škole budućnosti izdvaja se model koji ćemo nazvati Globalna škola usmerena na učenika (normativno i praktično). Ono što nas iznenađuje je predikcija da će se preferirana škola budućnosti izmeniti ali ne u pravcu veće digitalizacije obrazovanja već humanizacije i dobrovoljnosti. Najveća očekivana promena je u atmosferi škole, u odnosima svih učesnika školskog života. Globalna škola nije usmerena samo na učenje (informacije su dostupne uvek i svugde) već na potrebe učenika i društva. To je škola koja svakoga približava njegovim potencijalima. Viši nivo svesnosti ovde se doživljava kao alat uz pomoć kog će učenici biti opremljeniji da saznaju kakvu budućnost žele i kako da je stvore.

Cilj ovakve škole je globalni građanin, balansirana osoba, odnosno razvijen osećaj lične svrhe svakog učenika (engl. personal bliss), priprema za celoživotno učenje i doprinošenje opštem dobru (socijalna pravda). Globalna škola učenike osnažuje za rešavanje ekološke krize, društvenih i etničkih konflikata, društvenih problema, uz fokus na razvoju odgovornosti pojedinca. Ovakva škola je u skladu sa Tagorinom vizijom škole kao aktivnog inter-kulturalnog i mirovnog istraživanja u kome kreativne ideje i imaginacija cvetaju.

Globalna škola usmerena na učenika imaće neke (ili sve) od narednih karakteristika:

- Prilagođavanje potrebama učenika jer će u suprotnom biti zamenjena novim tehnologijama, usled razvoja učenja na daljinu odnosno integrisanje tehnologije u učenje.

- Poštovanje Drugog izdvojeno kao princip. Ovakva škola je neautoritativna i izrazito participativna, demokratska sredina. Poštuje se učenik i njegove odluke 
i akcije, uključujući i odluku da ne učestvuje u obrazovanju. Učenici su aktivno uključeni u obrazovanje, imaju ili delimičnu kontrolu nad svojim obrazovanjem (uključujući ciljeve i sadržaje obrazovanja) kao i prilike da pokažu i primene stečeno znanje i razumevanje, do toga da imaju potpunu kontrolu i samostalno definišu svrhe, potrebe i pristupe u obrazovanju.

- Globalna, fleksibilna u pristupima, orjentisana na mir, duhovnost, budućnost, kritičnost i održivost. Ovakva škola navodi i podstiče učenika da se pita šta je dobra škola za mene.

- Pruža jednako obrazovanje za sve, bez obzira na etničko, socijalno i drugo poreklo i sredinu (ne samo deklarativno već i u praksi).

- Integracija formalnog, neformalnog i informalnog obrazovanja, jedinstvo teorije prakse odnosno teorija o kojima poučavamo i prakse koju živimo, povezanost formalnog i neformalnog kurikuluma (učenici dobijaju poene za aktivnosti koje nisu u formalnom kurikulumu ali koje samostalno biraju prema ličnim sklonostima i interesovanjima).

- Učenje kroz pokušaje i greške, fleksibilno i kreativno, podržava razvoj kritičkog mišljenja i različitih vrsta pismenosti (razvoj personalne, interpersonalne i duhovne pismenosti kroz rešavanje konflikata, nošenje sa sajber nasiljem, rešavanje ekološke krize,...) i različitih inteligencija. Aktivno učenje, iskustveno učenje, učenje kroz delovanje. Osnaživanje unutrašnje motivacije. Razvija intelektualnu nezavisnost, sposobnost za učenje, pronalaženje informacija i donošenje odgovornih odluka.

- Individualizovana, fleksibilna i lično orjentisana škole, jer je takvo i društvo budućnosti.

\section{ZAKLJUČNA RAZMATRANJA}

Sa ulaskom u novi milenijum, većina ljudi je svesna da se nalazimo usred najdramatičnije tehnološke revolucije $u$ istoriji civilizacije, koja menja sve, od načina na koji radimo, komuniciramo i provodimo svoje slobodno vreme. Tehnološka revolucija, koncentrisana na informacije, komunikacije i multumedijske tehnologije, je često interpretirana kao začetnica „društva znanja” ili ,informacionog društva", u kome je obrazovanju dodeljena centralna uloga u svim aspektima života. Ovaj proces ,,velike transformacije”. kako ga Kelner naziva (Kellner, 2006), predstavlja ogroman izazov za sve koji su posvećeni obrazovanju, izazov u vidu preispitivanja naših osnovnih uverenja o primeni novih tehnologija u obrazovanju na kreativne i produktivne načine, kao i restruktuiranju obrazovanja (školovanja) tako da može konstruktivno i progresivno odgovoriti na tehnološke i socijalne promene koje u ovom momentu doživljamo (Kellner, 2006). Prema Kelneru, savremena kritička teorija obrazovanja mora da teži ka rekonstrukciji obrazovanja, ne kako bi ono odgovorilo na agende kapitalizovanih i visoko-tehnokratizovanih industrija, već da bi obrazovanje postalo radikalno demokratizovano u cilju ostvarenja ideja progresivnih teoretičara (Djui, Freire, Ilič) prema kojima odgovorno obra- 
zovanje uvek kao cilj ima razvoj individualnosti, građanskog duha i zajedništva, socijalne pravde i vodi do jačanja demokratskog učešća u svim aspektima života (Kellner, 2006). Saglasni sa ovim su i rezultati naše futurološke studije. Nasuprot očekivanjima da su globalizacija i tehnologizacija (virtuelizacija sveta/obrazovanja), dva ključna pravca savremenih promena u sferi obrazovanja (i društva uopšte), rezultati naše studije pokazuju da ova dva pravca nisu željeni pravci promena prema mišljenjima stručnjaka. Željene budućnosti škole kreću se u smeru povratka tradicionalnim, humanističkim vrednostima sa jedne strane, dok sa druge strane u smeru ponovnog integrisanja učenja u zajednicu a dece i mladih u svet odraslih. Ni jedan od ovih pravaca u suštini nije nov, ali isto tako ne pretpostavlja vraćanje na arhaične modele škole. Isto tako, ni jedan od naših alternativnih modela ne predstavlja sliku škole koju bi bilo moguće ostvariti reformama unutar obrazovnog sistema. Ovde govorimo o značajnoj, sistemskoj i koncepcijskoj promeni obrazovnih filozofija, politika i praksi. Takva promena je neodvojiva od promene društvenog konteksta u kom je obrazovanje situirano, odnosno od oslobađanja obrazovanja od društveno-politički nametnutih funkcija. Aktuelno društvo nije dovoljno zrelo za takvu vrstu liberacije obrazovnih uticaja, što jasno vidimo prateći aktuelne reforme obrazovanja koje redom idu u smeru centralizacije, standardizacije, ujednačavanja, sve veće i sve strožije kontrole nad formom (ishodi učenja, završni ispiti, standardi kompetencija nastavnika, licenciranje, i td.). Da li ćemo u ne tako dalekoj budućnosti postići da se bavimo suštinom obrazovanja, pitanje je na koje smo ovim radom tražili odgovor.

Tamara P. Borovica, Svetlana M. Kostović

\title{
ŠKOLA BUDUĆNOSTI - PRIKAZ DELFI STUDIJE O ALTERNATIVNIM BUDUĆNOSTIMA ŠKOLE
}

\begin{abstract}
REZIME
Na relevantna pitanja kakvo savremeno obrazovanje treba da bude, da bi odgovorilo na potrebe života u XXI veku?, kakva škola treba da bude da bi se učenici u njoj pripremali za intenzivan razvoj i neizvesnu budućnost savremenog sveta (poznatog pod sintagmom društvo rizika)?, $i$ da li obrazovanje treba da bude priprema za određene budućnosti (zvanične i nezvanične) na način na koji ih vide ,važni" stručnjaci, ili obrazovanje treba biti usmereno na stvaranje željenih, preferiranih vizija budućnosti?, autorke odgovore traže u futurologiji obrazovanja. Značaj futurološkog proučavanja obrazovanja se nalazi u činjenici da je svaki pristup obrazovnim reformama inherentno zasnovan na skrivenim idejama o budućnosti. Oslanjajući se na principe futurološke pedagogije, koja u proučavanju budućnosti obrazovanja uzima u obzir izmenjeni kontekst savremenog i budućeg života civilizacije, autorke predstavljaju osnovne rezultate futurološke Delfi studije realizovane sa ciljem identifikovanja potencijalnih alternativnih pravaca razvoja škola budućnosti.

U drugom delu rada autorke ukratko predstavljaju rezultate Delfi studije urađene na međunarodnom, ekspertskom uzorku intenziteta sa ciljem istraživanja alternativnih vizija preferiranih škola budućnosti. Autorke ukazuju da je ovakva kritička analiza budućnosti obrazovanja neophodna kako bi se razotkrili nametnuti scenariji budućnosti i umesto njih kreirali alternativni modeli
\end{abstract}


škola budućnosti, praveći razliku između verovatnih, mogućih, poželjnih i planiranih budućnosti obrazovanja. U radu su predstavljena tri identifikovana modela preferiranih škola budućnostiIntegrisana škola, Škola kontinuiteta i Globalna škola usmerena na dete.

Tamara P. Borovica, Svetlana M. Kostović

\title{
SCHOOLS OF THE FUTURE - REVIEW OF DELPHY STUDY ON ALTERNATIVE FUTURES OF SCHOOL
}

\begin{abstract}
SUMMARY
Concerning relevant questions what modern education should be in order to respond to the needs of life in the twenty-first century?, what school should be in order to help students to prepare for the intense development and the uncertain future of the modern world (known as the risk society)?, and should education be preparing for certain futures (official and unofficial) as they are seen by ,,important ,experts, or education should aim at creating preferred visions of futures?, the authors look for the answers in futurology of education. Importance of futurological studies of education lies in the fact that every approach to educational reforms is inherently based on the hidden ideas of the future. Relying on principles of futuristic pedagogy, which in the study of futures of education takes into account changing contexts of modern and future life of civilization, the authors present the results of futuristic Delphi study carried out with the aim of identifying potential alternatives of future schools.

In the second part of the paper authors briefly present results of the Delphi study realized at the international, expert sample of intensity, with an aim of exploring alternative preferred visions of futures of schools. The authors suggest that critical analysis of the future of education is necessary in order to expose imposed scenarios of the future and create alternative models of schools of the future, making the distinction between the probable, possible, desirable and planned future education. In the paper, authors shortly presented three identified desirable models of schools of the future - Integrated School, School of Continuity and Global Child Centered School.

Key words: critical theory of education, schools of the future, futurology of education, Delphy study.
\end{abstract}

\section{LITERATURA}

Dalkey, N. (1969). The Delphi method: An experimental study of group opinion. SantaMonica, CA: United States Air Force Project RAND.

Egan, K. (2008): The Future of Education: Reimagining our schools from the ground up, New Haven and London: Yale University Press;

Egan, K. (2010): Learning in Depth: a simple innovation that can transform schooling, Chicago and London: The University of Chicago Press;

Gidley, J. (2001): Globalization and its Impact on Youth, in Journal of Futures Studies, (Vol 6, No 1, August), pp. 89-106.

Gidley, J., Batemen, D.\& Smith, C.( 2004): Futures in Education: Principles, practice and potential, Melbourne, Australia: Australian Foresight Institute, Swinburne University of technology;

Gidley, J. (2008): BEYOND HOMOGENISATION OF GLOBAL EDUCATION: Do alternative pedagogies such as Steiner Education have anything to offer an emergent global/ising 
world? In S. Inayatullah, M. Bussey \& I. Milojevic (Ed.) Alternative Educational Futures: Pedagogies for an Emergent World, Sense Publications, Rotterdam, Netherlands, pp.253268.

Gidley, J. \& Hampson, G. (2008): Integral perspectives on school educational futures, in In S. Inayatullah, M. Bussey \& I. Milojevic (Ed.) Alternative Educational Futures: Pedagogies for an Emergent World, Sense Publications, Rotterdam, Netherlands, pp.253- 268.

Gordon, T. J. (2003): The Delphi method. In J. C. Glenn \& T. J. Gordon (Eds.), Futures research methodology-V2.0. Washington, DC: American Council for the United Nations University; Holzman, L. (1997): Schools for Growth: Radical alternatives to current educational models, Mahwah, New Jersey: Lawrence Erlbaum Associates;

Ilič, I. (1980): Dole škole, Beograd: Beogradsko izdavačko- grafički zavod, Biblioteka XX vek.

Kellner, D. (2006): Toward a Critical Theory of Education, in Critical Theory and Critical Pedagogy Today. Toward a New Critical Language in Education, edited by Ilan Gur-Ze'ev. University of Haifa: Studies in Education, 49-69.

Milojević, I. (2002): A Selective History of Futures Thinking, From: "FUTURES OF EDUCATION: FEMINIST AND POST-WESTERN CRITIQUES AND VISIONS”, PhD Thesis, School of Education, The University of Queensland, 2002.

Milojević. I. (2005): Educational futures, Dominant and contesting visions, London \& New York: Routledge;

Moravec, J. W. (2007): A New Paradigm of Knowledge Production in Minnesota Higher Education: A Delphi Study, UNIVERSITY OF MINNESOTA: PhD Thesis Defended.

Pedagoški leksikon (1996): Beograd: Zavod za udžbenike i nastavna sredstva;

Сузић, Н. (2012): Футурологија у педагогији и социјалним наукама, Бања Лука: ЕКТОС; Toffler, A. et al (1974): Learning for tomorrow, The Role of the Future in Education, New York: Random House.

Vrcelj, S., Mušanović, M. (2001): Prema pedagoškoj futurologiji : (škola budućnosti), Rijeka: Hrvatski pedagoško-književni zbor. 